\title{
Historical Chinese Women's Social Status Reflected in Traditional Chinese Language From Critical Discourse Analysis Perspective
}

\author{
YE Xiao-ya \\ Beijing Foreign Studies University, Beijing, China
}

\begin{abstract}
Critical discourse analysis views language as a form of social practice and focuses on the ways social and political domination are reproduced in verbal and written language. It primarily deals with injustice and inequality. This paper studies how traditional Chinese language reflected historical Chinese women's social status from critical discourse analysis perspective. The author intends to answer the following two questions: (1) How was traditional Chinese language used differently regarding males and females? and (2) How did such difference reflect the social status of historical Chinese women? Results show that in traditional Chinese language women were almost invisible, they were degraded and treated as inferior, incompetent, dependent, and unintelligent individuals, and their voices were not expected to be heard in public.
\end{abstract}

Keywords: critical discourse analysis, language and gender, historical Chinese women, traditional Chinese language, social status

\section{Introduction}

Critical discourse studies originate from three overlapping intellectual traditions: discourse studies (Derrida, 1974; Foucault, 1972; Pecheux, 1975), feminist post-structuralism (Butler, 1990; Davies, 1993), and critical linguistics (Fowler, Hodge, Kress, \& Trew, 1979; Halliday \& Hasan, 1989; Hodge \& Kress, 1979, 1993; Pecheux, 1975; Pennycook, 2001). Critical discourse analysis focuses on how language functions as a cultural tool and mediates relationships of power and privilege in social interactions, institutions, and bodies of knowledge (Bourdieu, 1977; Davies \& Harre, 1990; Foucault, 1972; Gee, 1999).

This paper focuses on language and gender in traditional Chinese language, and the author first differentiates sex and gender. Wardhaugh (2002, p. 313) points out that sex is usually biologically determined; gender is a social construct involving genetic, psychological, social, and cultural differences between males and females. Language is like a mirror, which reflects the society of human beings. Talbot (1998) claims that women's subordinate status is reflected in the language used about them and the language they use. This study focuses on how traditional Chinese language reflected the social status of historical Chinese women. The following two questions are to be answered: (1) How was traditional Chinese language used differently

YE Xiao-ya, Ph.D., School of English and International Studies, Beijing Foreign Studies University. 
regarding males and females? and (2) How did such difference reflect the social status of historical Chinese women?

\section{Women Were Almost Invisible in Traditional Chinese Language}

\section{The Invisibility of Women in Terms of Names}

In Chinese culture, name is an important marker which shows the identity of the individual. Chinese names are usually created by the children's parents or grand-parents. Semantically, each Chinese character contains a certain meaning, and when the parents name their babies, they choose one or two Chinese characters, which convey the expectations they have for their babies, as the children's names. In the past when the parents named their boys, they treated it very seriously, and it would take them lots of time and energy to deal with it. However, traditionally Chinese women, especially women from the lower social status, did not have official or formal names. When the parents named their daughters, they treated it very easily: They might just choose one or two characters randomly because the society believed that it was unnecessary for women to have formal names.

\section{The Invisibility of Women in Terms of Addressing}

Since traditionally the society did not treat Chinese women's names seriously, one question came out: How did other people address them? This question can be elaborated and discussed in two situations: before and after the marriage of historical Chinese women.

Before historical Chinese women got married, people usually addressed them in two ways: (1) They gave them some nick names (informal names), such as the name of a certain flower or a certain tree, and used the nick names to address them and (2) they just called them "First Girl" (if she was the first daughter), "Second Girl" (if she was the second daughter), or "Little Girl" (if she was the youngest daughter).

After historical Chinese women got married, people also addressed them in two ways. Firstly, they used the woman's husband's name plus "house" and plus "s". For example, if her husband's name was LIN Ji-xiang (Lin was his family name, and Ji-xiang was his given name which meant luckiness), then when other people referred to the wife, they would call her "LIN Ji-xiang's house's". Secondly, if the woman could bare a son, she would have another way to be addressed: her son's name plus "'s mother". For example, if her son's name was LIN Fu-gui (LIN was the son's family name and Fu-gui was the given name which meant fortune), the mother would be addressed as "LIN Fu-gui's mother".

In a word, a historical Chinese woman's identity was conveyed by her relationship with her father, her husband, and her son. Another way to interpret this is without a father, a husband, or a son, a woman was not treated as an individual in the realistic world.

\section{The Invisibility of Women in Terms of Family Tree}

Traditionally, each family in China had a family tree. The higher social status a family belonged to, the more complicated the family tree was. However, in most cases women were not included in the family tree. That is to say before a young girl got married, she was not in the family tree of her maiden family, and after she got married, she was not in the family tree of her husband's family, either. 
Family tree was very important in traditional Chinese culture, because it represented an individual's existence in the world and the relationship of a certain individual with his or her family members and the outside world. Unfortunately, women were absent in the family tree. On one hand, women did not participate in any public activities, and therefore, they did not have any tie to the outside world; on the other hand, even if women stayed at home for their whole life, and took charge of most domestic work, they were almost invisible within the family.

Moreover, family tree also represented the prosperity of a family. The more sons a family had, the more booming the family was because the family had the best chance to carry on the family line. In traditional Chinese culture, people attached significance to carrying on the family line. China was a feudal society for thousands of years, and filial piety was considered as the most significant virtue a person should have. Mencius (Meng Tzu), a Chinese philosopher who was regarded as the most famous Confucian after Confucius himself, stated that the most ungrateful and the most unfilial behavior was not to have a male descendent. The reason was that traditionally only males could carry on the family line, and when a family did not have a male descendent, it meant the extinct of the whole family.

\section{Many Expressions in Traditional Chinese Language Degraded Women and Treated Them as Inferior, Incompetent, and Unintelligent Individuals}

In traditional Chinese language, there was an idiom that meant "Even women and children know that", and people used it frequently in the following context. An important event took place or a well-known person did a great job, and person A talked to person B about this issue, but person B did not know that. Therefore, person A felt quite surprised and would say "What? You have never heard of it? Come on! Even women and children know it". The implication of this idiom was that women were ignorant and not well-informed. Even though women were adults, the horizon of their life was the same, if not worse, as children. Many other expressions conveyed similar meanings. People used to say "A talentless woman has virtue", "Ignorance is a woman's virtue", "You are narrow-minded or short-sighted, just like a woman", "You are as weak as a woman", "You are a man, and you should have the indomitable spirit. As a man, your feet should touch the ground and your head can touch the sky. So don't behave like a woman", and so on.

Furthermore, historical Chinese women's speech was regarded as trivial and nagging. For instance, if a person mentioned one issue repeatedly, and this behavior annoyed some other people around him, they would way, "Don't nag like a woman. We don't like it". Or if a person talked behind another person's back, other people might say "Stop it. Don't gossip like a woman".

From the above examples we can see men's speech was the norm and women's speech was devalued. This language phenomenon in tradition Chinese language is in accordance with what Talbot (1998) mentioned: "The overall effect is a picture of women's language as inferior and deficient. Men's language is, by implication, superior and the norm from which women deviate" (p. 40).

\section{Traditional Chinese Language Put Women in the Status of Dependents and This Language Phenomenon Reflected the Asymmetrical Gender Status in Society}

The verb “marry” in Chinese had two characters, “娶” and “嫁”. “娶” was used when the bridegroom was 
the subject of a sentence, while "嫁” was used when the bride was the subject of a sentence. Chinese is a pictographic language, and the above two characters "娶” and "嫁” conveyed meanings in them. The character “娶” was composed of two parts: the top part "取” meant "to get" and the bottom part “女” meant "female". Therefore, the literal meaning of “娶” was to get a female as a wife. The character "嫁” was also composed of two parts: the left part “女” meant female, and the right part “家” meant “house”. The predicate “娶” was used as a verb independently, while the predicate “嫁” was usually used with another character “给”, which meant “to be given", to convey the meaning of "marry”. “嫁给” was used to express the meaning that a woman marries a man. Therefore, the literal meaning of “嫁给” was that a woman was given to a man and had a family. Based on the two predicates “娶” and “嫁给”, we can see the asymmetry of men and women's status in terms of marriage. A man was an independent individual and marriage to him was to get a wife, whereas a woman was a dependent individual, and she was like a product that was given to a man in the marriage.

Moreover, in traditional Chinese language many metaphors were used to describe the asymmetrical gender status in society. For example, Shi Jing, which was translated variously as the Classic of Poetry, the Book of Songs, or the Book of Odes, was the earliest existing collection of Chinese poems, and it contained 305 poems, some of which were written as early as 1000 BC. In Shi Jing, a metaphor was used to describe the happiness of a family having a new born baby. If a family had a baby boy, it was called “the happiness of '璋” (“璋' meant jade)"; if the family had a baby girl, it was called "the happiness of '瓦' ('瓦' meant a part of spinning wheel)". The implication was that suppose a baby boy was born, the parents would give him a jade to play with, and in traditional Chinese culture, jade was the symbol of power and fortune; whereas if a baby girl was born, the parents would just give her a small part of the spinning wheel to play with so that she could manage the domestic work and serve her family members when she grew up.

More metaphors were used daily to convey similar meanings. For instance, "If a woman marries a rooster, she should follow the footsteps of the rooster; if a woman marries a dog, she should follow the footsteps of the dog". Traditional marriage in China was arranged marriage, and a woman did not know what kind of person her husband was before she married him, but she was expected to be submissive and dependent on her husband no matter who he was. As long as he was the woman's husband, he was the heaven (God) in her life. Even if he was an animal, like a rooster or a dog, the wife was still expected to be in guidance of her husband.

Women were also compared to "shirts" frequently. One of them was that "Brothers are like your hands and feet; wives are like your shirts". The indication here was that brothers were very important to a man because they were the real family members who could carry on the family line and assist the man with his career, while wives (in Chinese feudal society, a man was allowed to have one official wife and several concubines legally) were insignificant to the man just like his shirts. The implications were (1) a real man should never treat his wives seriously because women were trivial in a man's life; (2) a man could have as many women as he wanted as long as he could support them financially just like he could have as many shirts as he wanted as long as he could pay for them; (3) a man could choose which woman he would sleep with at night just like he could choose which shirt he would put on in the day; and (4) he could dump his wife at his wish just like he could throw away a shirt if he did not like it any more since in historical Chinese feudal society a man could terminate the marriage without the agreement of his wife or concubines. 


\section{Many Poems in the History of Chinese Literature Also Reflected Women's Inferior Social Status}

For instance in 300 Tang Poems, MENG Jiao (751-814), a famous Chinese poet, composed a poem entitled A Song of a Pure-Hearted Girl. The following is the English translation version of this poem.

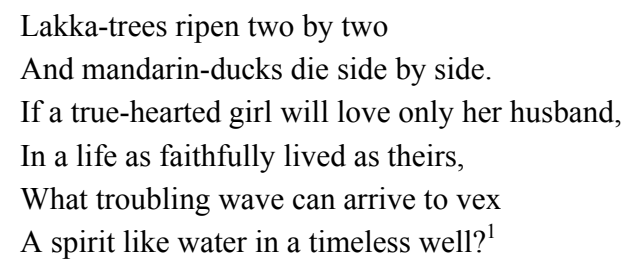

Readers need to read between lines so as to get the implications of the poem. The first two lines of this poem presented two images: Lakka-trees were like a couple, and they died together; a couple of mandarin-ducks also died one with the other. In the next two lines, the subjects of the poem moved from the lakka trees and the mandarin-ducks to a faithful girl. If the husband of the faithful girl passed away, she was expected to commit suicide to accompany him just like the lakka-trees and the mandarin-ducks which would not live alone without the partner. In the last two lines, metaphors were used: The heart of the loyal girl was the water in a timeless well, which would never be disturbed by any wave. Therefore, only her husband could exist in the faithful girl's heart, no matter whether he was alive or dead.

This poem shows that in historical Chinese feudal society, people's expectation for a woman was significantly differently from their expectation for a man. A man at that time was never encouraged to die for love; instead he could terminate his marriage whenever he wanted without the need of agreement with anyone, and he could also have as many legal concubines as possible as long as he could support them financially. Nevertheless, a woman could only marry once in her whole life, she could never get divorced unless her husband terminated the marriage, and she was expected to die if her husband passed away in order to show her faithfulness to her husband.

\section{In Chinese History, Women Did Not Have the Right to Speak, and They Were Expected to Always Keep Silent in Public}

Talbot (1998) states "Being forced to remain silent, to have no public voice, is like being invisible" (p. 185) Historical Chinese women were not expected to appear in public situations, and were not expected to express her ideas. For instance, in traditional Chinese culture people attached great importance to fealty, and people held the view that filial piety to one's parents was the best virtue that human beings could ever have. In Chinese feudal history, kowtowing (to kneel and touch the forehead to the ground in expression of deep respect, worship, or submissions) was the most formal etiquette to a superior individual. A son or a grandson usually did this to his mother or his grandmother to show his respect to her. It seemed as if a senior woman, who had male descendents, had high status within her family. Nevertheless, the fact was that when some guests visited this family and the whole family treated the guests with sumptuous diner, the mother or the grand-mother was not allowed to sit around the table and had the diner with the guests. The reason was that the guests would feel

\footnotetext{
1 Translation from http://wengu.tartarie.com/wg/wengu.php?no=44\&l=Tangshi.
} 
humiliated if they were treated by women rather than by men, and in this way even the most senior woman in a family was excluded from public settings. Another vivid example to support the above idea was that when a wife stayed at home alone, and someone knocked at the door saying "Is anyone at home?", the wife usually said "No one is at home". The reason was that the wife was expected to be absent and remain silent. She could not make any decision and was not able to be responsible for any issue.

\section{Conclusion}

This paper intends to study how traditional Chinese language functioned as a mirror to reflect the social status of historical Chinese women. Findings show that in traditional Chinese language women were almost invisible in terms of names, addressing and family tree, many expressions and poems degraded women and treated them as inferior, dependent, incompetent, and unintelligent individuals, women's voices were not valued and they were expected to be in silence, especially in public settings.

\section{References}

Bourdieu, P. (1977). Outline of a theory of practice. Cambridge, UK: Cambridge University Press.

Butler, J. (1990). Gender trouble: Feminism and the subversion of identity. London: Routledge.

Davies, B. (1993). Shards of glass: Children reading and writing beyond gendered identities. Cresskill, NJ: Hampton Press.

Davies, B., \& Harre, R. (1990). Positioning: The discursive production of selves. Journal for the Theory of Social Behavior, 20(1), 43-63.

Derrida, J. (1974). Of grammatology. Baltimore: Johns Hopkins University Press.

Foucault, M. (1972). The archeology of knowledge and the discourse on language. New York: Pantheon Books.

Fowler, R., Hodge, B., Kress, G., \& Trew, T. (1979). Language and control. London: Routledge.

Gee, J. P. (1999). An introduction to discourse analysis. New York: Routledge.

Halliday, M. A. K., \& Hasan, R. (1989). Language, context and text: Aspects of language as a social-semiotic perspective. Oxford, UK: Oxford University Press.

Hodge, R., \& Kress, G. (1979/1993). Language as ideology (2nd ed.). London: Routledge.

Meng, J. (751-814). A song of a pure-hearted girl. Translation retrieved from http://wengu.tartarie.com/wg/wengu.php?no=44\&l=Tangshi

Pecheux, M. (1975). Language, semantics and ideology. New York: St. Martin's Press.

Pennycook, A. (2001). Critical applied linguistics: A critical introduction. Mahwah, NJ: Lawrence Erlbaum.

Talbot, M. M. (1998). Language and gender an introduction. Malden, MA: Blackwell Publishers.

Wardhaugh, R. (2002). An introduction to sociolinguistics. Blackwell Publishing. 